\title{
"Audit committee attributes, board attributes and market performance of listed deposit money banks in Nigeria"
}

\begin{tabular}{|c|c|}
\hline & Oluwatamilore Omotoye (D https://orcid.org/0000-0001-7706-5804 \\
\hline & Kingsley Aderemi Adeyemo (D) https://orcid.org/0000-0002-3583-0819 \\
\hline \multirow[t]{3}{*}{ AUTHORS } & Tumininu Omotoye (D https://orcid.org/0000-0001-6137-7264 \\
\hline & Faith Okeme (D https://orcid.org/0000-0002-1632-1605 \\
\hline & Andrew Leigh (D https://orcid.org/0000-0001-9997-6270 \\
\hline ARTICLE INFO & $\begin{array}{l}\text { Oluwatamilore Omotoye, Kingsley Aderemi Adeyemo, Tumininu Omotoye, Faith } \\
\text { Okeme and Andrew Leigh (2021). Audit committee attributes, board attributes } \\
\text { and market performance of listed deposit money banks in Nigeria. Banks and } \\
\text { Bank Systems, 16(1), 168-181. doi:10.21511/bbs.16(1).2021.15 }\end{array}$ \\
\hline DOI & http://dx.doi.org/10.21511/bbs.16(1).2021.15 \\
\hline RELEASED ON & Tuesday, 30 March 2021 \\
\hline RECEIVED ON & Tuesday, 11 August 2020 \\
\hline \multirow[t]{2}{*}{ ACCEPTED ON } & Tuesday, 15 December 2020 \\
\hline & \begin{tabular}{|l|l|l|l|l|l|}
$(c)$ \\
\end{tabular} \\
\hline LICENSE & $\begin{array}{l}\text { This work is licensed under a Creative Commons Attribution } 4.0 \text { International } \\
\text { License }\end{array}$ \\
\hline JOURNAL & "Banks and Bank Systems" \\
\hline ISSN PRINT & $1816-7403$ \\
\hline ISSN ONLINE & $1991-7074$ \\
\hline PUBLISHER & LLC "Consulting Publishing Company "Business Perspectives" \\
\hline FOUNDER & LLC "Consulting Publishing Company "Business Perspectives" \\
\hline
\end{tabular}

NUMBER OF REFERENCES

76

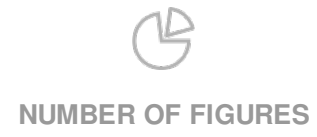

0
NUMBER OF TABLES

4

(C) The author(s) 2023. This publication is an open access article. 


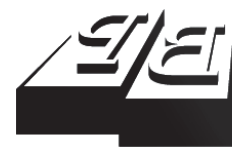

\section{BUSINESS PERSPECTIVES}

LLC "CPC "Business Perspectives" Hryhorii Skovoroda lane, 10, Sumy, 40022, Ukraine www.businessperspectives.org
Received on: $11^{\text {th }}$ of August, 2020 Accepted on: $15^{\text {th }}$ of December, 2020 Published on: $30^{\text {th }}$ of March, 2021

(C) Oluwatamilore Omotoye, Kingsley Adeyemo, Tumininu Omotoye, Faith Okeme, Andrew Leigh, 2021

Oluwatamilore Omotoye, Bsc, Department of Accounting, Covenant University, Ota, Ogun State, Nigeria. (Corresponding author)

Kingsley Adeyemo, Ph.D., ACA, Department of Accounting, Covenant University, Ota, Ogun State, Nigeria.

Tumininu Omotoye, Bsc, Department of Business Management, Covenant University, Ota, Ogun State, Nigeria.

Faith Okeme, Bsc, Department of Accounting, Covenant University, Ota, Ogun State, Nigeria.

Andrew Leigh, Bsc, Department of Accounting, Covenant University, Ota, Ogun State, Nigeria.
Oluwatamilore Omotoye (Nigeria), Kingsley Adeyemo (Nigeria), Tumininu Omotoye (Nigeria), Faith Okeme (Nigeria), Andrew Leigh (Nigeria)

\begin{abstract}
This paper aims to discover the association between various audit committee and board attributes and the market performance of listed deposit money banks in Nigeria. The study intends to determine the influence of audit committee size, gender diversity, expertise, board size and board shareholding on market performance (measured by Tobin Q). Panel data was gathered from twelve (12) banks listed on the Nigerian Stock Exchange from 2013 to 2017. The study used fixed and random regression analysis. The results concluded that the association between audit committee size, board size and Tobin Q was negatively significant. There was a positively significant impact of audit committee gender diversity and audit committee expertise on Tobin Q. The study showed a positive but insignificant influence of board shareholding on market performance. The results imply that weakness in governance structures might lead to lower market performance. This study recommends that firms ensure that appointment criteria prioritize knowledge and competence, and regulatory bodies are also encouraged to track the compliance of listed firms with corporate governance regulations.
\end{abstract}

Keywords

JEL Classification

\section{INTRODUCTION}

Banks dominate in providing substantial access to adequate credit services for various individuals in many countries. They offer both national and international funds, resources and investments designed to impact the country's economic growth. Financial investments are extremely important to diverse types of banking enterprises in countries with developing markets (Ogura, 2018). Developing a market-oriented and viable financial system is vital for all firms in all industries, and market performance, market stability and profitability are key indicators of an entity's growth (Acharya, 2017). Ultimately, market performance is a crucial factor for investors and is affected by diverse functions and components used by entities to achieve both internal and external goal-oriented missions and visions (Aguilera \& Jackson, 2010). Financial difficulties that many companies have faced in recent years have contributed to the need for ethical/professional standards and controls to gain credibility in the financial accounts. These deficiencies allegedly exist due to conflicts of interest, board inefficiency, inefficiency of external auditors, lack of audit committee independence and shortcomings in their governance structures (Adeyemo, 2012). These challenges intensely distressed numerous institutions such as 
Oceanic bank, Intercontinental bank, Spring bank, Afribank, Wema bank, Savannah bank, Finbank, leading to series of investment losses (Ojeka et al., 2014).

Hence, distinct external and internal frameworks have been adopted by banks and other entities to prevent conflicts and failure (Adeyemo et al., 2020). The Nigerian code of corporate governance was revised by the Securities and Exchange Commission (SEC) to restore investors' confidence. Constitutionally, to safeguard and protect the firm's environment, Nigerian deposit money banks (DMB) are legally required by regulators to set up adequate corporate governance factors, including the audit committees and the board, in order to minimize agency conflicts, enhance growth, performance, profitability and overall company value (Bilal et al., 2018). Corporate governance growth is a critical framework for the global economy as good governance is related to international and local growth, competitiveness and strategies (Pillai \& AlMalkawi, 2018). The framework provides procedures and guidelines for every interconnected organizational operation to ensure administrative success, profitability and reliable quality of service (Claessens \& Yurtoglu, 2013). The approaches, tactics and actions of the audit committee and the board are therefore sometimes linked with the overall performance and success of market activities.

Despite numerous governance codes, conducts and reforms adopted by financial entities, there have been multiple scandals where executives have acted illegally or in bad faith against their shareholders. Nonetheless, several researchers try to assess the link between governance systems and performance, and inquires have been made on the ability of good governance to ensure that businesses operate properly and thus improves performance. There is a central question as to the degree of the impacts of audit committee and board attributes on the market performance of developing or emerging countries, since they are mostly characterized by weak or underperforming banking institutions. Uwuigbe (2013) conducted an analysis that was centered on corporate governance and Nigerian firms' financial performance with an exclusion of the financial sector. Ojeka et al. (2014) also conducted a study regarding the country's manufacturing sector. Therefore, given the importance of board of directors and audit committees, this study aims to add to existing knowledge by revisiting certain governance features where there has been little or no addition to literatures and particularly focusing on the effects of the attributes of the audit committee and board on the market performance of banks in Nigeria, as a developing country, since previous research has focused more on the market performance of businesses in other industries.

This study aims to explore the degree to which audit committee and board features affect the market performance of banks in Nigeria. To conclude on the possibility that compliance of banks to governance codes might influence their market performance, the work implements one performance, three audit committee and two board indicators. The specific objectives are therefore to ascertain the extent to which audit committee size, audit committee gender diversity, audit committee expertise, board size and board shareholding influence market performance of listed banks in Nigeria.

\section{LITERATURE REVIEW AND HYPOTHESES}

This segment discusses the concepts, theories, empirical reviews and the hypotheses of this work.

\subsection{Market performance}

Kakanda et al. (2016a) reasoned that the durability and growth of banks is measured according to their corporate and financial performance. The performance of companies is viewed differently by various parties. Some view corporate performance as a way of proactively using the available resources to attain the set aims and goals of a company (Marn \& Romauld, 2012), others view performance in the context of maximizing shareholder wealth (Berger \& Patti, 2002). The performance of a firm can be analyzed when at the close of a financial year, the shareholder achieves satisfaction compared with the start of a financial year. When assessing a firm's performance, different financial ratios such as return on capital employed (ROCE), return on assets (ROA) and return on equity (ROE) 
are applicable (Awinbugri \& Prince, 2019). The measure of firm performance used was Tobin's Q, because it evaluates both the market values of the business and the book values (Ankur et al., 2018; Ojeka et al., 2019b), it is a widely known standard indicator of long-run company performance. The utilization of the market value of equity will identify the future growth prospects of the business that could occur from exogenous factors to managerial decisions (Shan \& McIver, 2011).

\subsection{Audit committee attributes and market performance}

In achieving good governance, an Audit committee (AC) has a crucial responsibility of overseeing reporting processes and ensuring credibility and transparency in the reports. The major goal is to immunize the quality of presented financial reports (Oliver \& Grace, 2017), and other roles and functions include ensuring that financial statements are prepared according to implemented standards, overseeing the interactions among the management, employees and external auditors, facilitating principles and managing risk management processes (Zraiq \& Fadzil, 2018a). Studies show that the audit committee effectiveness construct is dimensional and subjective to diverse features such as independence, size, diversity, membership mix, meetings and financial expertise (Mohiuddin \& Karbhari, 2010). Despite various previous studies on the features of an audit committee, there has been little or no recent literature on some important features, including gender diversity of the audit committee members (Ibrahim \& Al harasees, 2019). For this work, the following indicators of audit committees are used (see the next subsection).

\subsubsection{Audit committee size}

The success of an audit committee is often attributed to the resources available, that is, the number of members in the committee. Audit committee size is an important element for the committee to properly oversee governance activities. The number of available members will probably assist in overcoming issues in the course of corporate reporting (Li et al., 2012). According to the regulatory bodies in Nigeria, the maximum number of committee memberships should be six (6), and regardless of the membership size, the committee must consist of representatives of directors, as well as shareholders. To foster effectiveness in guaranteeing that actions of the firm are in the interest of shareholders, the audit committee must have sufficient membership size to perform its responsibilities appropriately. Zraiq and Fadzil (2018a) studied the effect of an audit committee on firm performance and found that smaller committees with more exposure and knowledge are positively significant to firm performance, and the size of the audit committee has an important correlation with performance. Although, Afza and Nazir (2014) showed that there is a significant negative relationship between the size of an audit committee and firm performance because there is little room for flexibility in a larger committee. Theories suggest that organizations should set up a committee not so large as to be unfavorable, but reasonably large to guarantee successful monitoring (Allegrini \& Greco, 2011).

\subsubsection{Audit committee gender diversity}

In the performance of their duties, the attitude and ethical conducts of the male and female gender are said to be different. Previous studies show that the audit committee gender diversity and the involvement of a female member in committees has an impression on the corporation's decisions (Ibrahim \& Al harasees, 2019). Studies show that company teams with an equal gender representation perform significantly better when it comes to both sales and profits than male-dominated teams (Aldamen et al., 2018). The selection of a female audit committee member may be seen as critical information for market participants. According to previous literature, female members are capable of improving firm governance through their conservative and ethical qualities (Ibrahim \& Al harasees, 2019). Studies show indications that firms with female representation reduce the inherent risk of misstatements and are associated with lower audit fees (Mwangi et al., 2017). But, there are also arguments to support the idea that greater gender diversity may have a negative effect on the company's management and thus may not enhance its information environment. Several studies suggest that greater gender diversity produces more viewpoints and critical issues or can lead to obstacles within the company, possible discrimi- 
nation, increase in the likelihood of conflict, and reduction in cooperation, satisfaction, and engagement (Abad et al., 2017).

\subsubsection{Audit committee expertise}

The expertise criteria of an audit committee were included in Nigeria by the 2011 SEC Code and the 2006 Post consolidation CBN code, amongst other codes. Such codes require that an audit committee member must have at least financial management and accounting expertise (Asiriuwa et al., 2018). Juhmani (2017) stated that the presence of financial expertise would improve proficiency and capacity to detect and prevent earnings management. Kibiya et al. (2016) also stressed that the participation of a financially literate or competent member in financial management would improve the firm's performance. Li et al. (2012) stated that an audit committee with members who possess the required financial expertise is more equipped with the knowledge of necessary capital market consequences of financial statement disclosures that are expected to improve the quality of reporting and reduce the asymmetry of information. Therefore, in accordance with regulations of the corporate governance codes in Nigeria, the financial statement must be read and interpreted by not less than a single member of an audit committee.

\subsection{Board attributes and market performance}

The company's decision to adopt a specific corporate governance mechanism is controlled by numerous factors, including the entity's fundamental characteristics, board attributes and other corporative variables (Hay et al., 2017; Osundina et al., 2016). Governance mechanisms adopted by banks are used for improving organizational performance, contributing to new and existing market shares and improving the knowledge of business roles and obligation. Zabri et al. (2016) stated that the board is a very important corporate governance framework. The board performs important and critical roles in each company. Board based criteria are believed to be a substitute for a company's corporate governance, the company's board is obligated to control performance by reconciling the interests of the shareholders and stakeholders. They set strategic directions and monitor compli- ance with decrees and guidelines. The board will equally be obligated to guarantee external auditor's integrity, professional skepticism and ethical consideration (Zabri et al., 2016). Previous research suggested that bank governance was directly correlated with market performance (Elmagrhi et al., 2017; Detthamrong et al., 2017; Andreou et al., 2016). In this paper, indicators of the board include the following (see the next subsection).

\subsubsection{Board size}

The size of the board of directors is a vital corporate governance structure, which is crucial to the management of any organization and essential in monitoring corporate governance effectiveness (Ntim \& Soobaroyen, 2013). Board size is the overall number of directors, non-executive and executive, in the firm. Since the directors of companies are alleged to affect organizational performance, it is very essential to ascertain the appropriate board size of a company. Although there is no standard board size, the Central Bank code prescribes a minimum of five and a maximum of twenty directors. Some businesses choose a small board size with the expectation that control will be effective and decision-making will be quicker, while some prefer the larger board size with the belief that it will lead to an expansion of expertise because more knowledge as well as skills are available (Hussainey \& Wang, 2010). Agency theory suggests that better organizational performance might be correlated with smaller board sizes because they are not likely to have as much problems in organizing and communication, and are likely to be more successful in controlling the activities of management (Isik \& Ince, 2016). While the resource dependency approach favors larger boards, it states that they could be helpful in limiting reliance on external resources and may give better opportunities for greater connections than smaller boards. According to Pathan and Faff (2013), whether small or large, the size of the board can negatively affect bank performance.

\subsubsection{Board shareholding}

In literature, the impact of board ownership/ director ownership has received considerable attention (Desoky \& Mousa, 2012). Separating control from ownership gives rise to conflicts of 
interest between investors and the board. Board ownership influences the degree to which owners' interests are congruent with the board or management. If directors have large stakes in a company's stock, their actions have an effect on their own wealth and they are probably less likely to take action that might decrease shareholders' wealth irrespective of how independent they are (Bhagat \& Bolton, 2013). Consequently, when ownership and management interests are combined through ownership concentration, performance might improve. Stock ownership by executives and members of the board gives them an incentive to improve performance. The output influence of board control is considered to be complex and uncertain (Scholtz \& Engelbrecht, 2015). Prior works have shown inconclusive results, the first claims imply that board ownership produces a balance of ownership and managerial interests, which positively influences performance. If the percentage of stocks owned by the board is high, they are more likely to make decisions compatible with maximizing the wealth of stockholders, since that will increase their own wealth (Jensen \& Meckling, 1976). The second claim suggests that high proportions of board ownership affect performance adversely, this argument suggests the possibility of absence in the connection between board ownership and performance.

\subsection{Empirical framework}

Hassan (2010) studied the corporate governance and performance structures of nine licensed deposit money banks in Nigeria for the period of 2013 to 2017. The paper utilized multiple regression techniques and found no correlation between board size, board composition, directors' shareholding, dividend policy, audit quality and financial performance (return on assets, net interest margin, Tobin's $\mathrm{Q}$ and earnings ratio). The research concluded that regulators should leave specific concerns of board size and board composition to the preference of banks.

Maxwell and Kehinde (2012) considered a relationship between corporate governance and bank performance by utilizing two governance metrics, board composition and ownership structure, and using market value to measure bank perfor- mance. The study utilized cross-sectional survey research design in analyzing data from a sample of 14 Nigerian banks quoted on the NSE. The authors found no association between indices of governance used in the analysis and performance. The results propose that board size should be limited to boost performance by reducing costs, since the board composition is not significantly associated with performance.

Al-Saidi and Al-Shammari (2013) obtained perspectives on the interaction between board composition and bank performance by sampling nine listed banks in Kuwait. To check this relationship, the analysis used ordinary least squares (OLS) and 2SLS. According to the findings of the OLS, only board size and the proportion of non-executive directors adversely influence the performance of the banks. The 2SLS findings showed that role duality has a positive effect on the performance of a bank, while board size has a negative influence on the performance of a bank. The study indicated their main drawbacks were smaller sample size and length of time.

Bebeji et al. (2015) assessed the extent to which board size and composition influence the performance of listed banks in Nigeria. The researchers adopted a multivariate regression analysis technique on five banks for a span of nine years. The research recorded the effect of board size on ROA and $\mathrm{ROE}$ to be negative, and the influence on bank performance by board composition to be significantly positive. The work suggested that firms possess sufficient board members and complexity and should be structured to ensure diverse levels of experience without losing independence.

Jadah and Adzis (2016) evaluated the link between board characteristics and bank performance for 20 Iraqi banks over a 10-year period from 20052014. The results showed that board characteristics significantly and positively impacted bank performance (proxied by return on equity).

Shukla et al. (2018) researched the effects of board characteristics on the market performance of 29 Indian banks listed on the National Stock Exchange from 2009 to 2016. Ten board features reflected the independent variables, and the dependent variable was proxied by Tobin Q. The re- 
sults showed that only three of the features (CEO duality, average number of boards served and number of meetings) were positively linked with market performance.

Osemene and Fakile (2019) analyzed the efficacy of an audit committee and the financial performance of Nigerian deposit money banks. Return on equity (ROE) was used as a measure of performance and independence, financial expertise and frequency of meetings were used as factors affecting financial performance. The study resolved that the financial experience and meetings of the audit committee had substantial control over financial performance.

\subsection{Theoretical underpinning}

\subsubsection{Agency theory}

The theory sets standards for the observation of the organizational relationship between different parties. The objective of the theory is to determine the best arrangement between the principal and the agent. Principals are responsible for appointing the agents to provide services on their behalf, and this encompasses relinquishing a considerable share of power to agents (Jensen \& Meckling, 1976). The audit committee and the board are therefore agents of the principals, they are charged with monitoring the performance of the firm in order to promote compliance to regulations, guidelines and standards. The notion of the theory is that if the concerned parties have different goals, access to information and propensity towards risk, the wealth of the principal may be minimized.

\subsection{Hypotheses}

Based on the literature review and study objectives, the research hypotheses are specified as follows:

$\begin{array}{ll}H_{1}: & \begin{array}{l}\text { Audit committee size has no significant impact } \\ \text { on the market performance of banks in Nigeria. }\end{array}\end{array}$

$\mathrm{H}_{2}: \quad$ Audit committee gender diversity has no significant association with the market performance of banks in Nigeria.

$H_{3}: \quad$ Audit committee expertise has no significant effect on the market performance of banks in Nigeria.
$\mathrm{H}_{4}$ : $\quad$ Board size has no significant connection with the market performance of banks in Nigeria.

$H_{5}: \quad$ Board shareholding has no significant effect on the market performance of banks in Nigeria.

\section{METHODOLOGY}

The study tests the hypotheses on deposit money banks listed on the Nigerian Stock Exchange. Following specific filtering patterns, the study draws twelve (12) banks from the 14 banks listed on the Nigerian Stock Exchange from 2013 to 2017. To arrive at the sample for the analysis, firms without relevant data desired for the study were excluded. The share prices of the firms for the market performance measure were found on the website of the Nigerian Stock Exchange, and the information with regard to audit committee and board variables was obtained through the Corporate Governance data provided in each annual report.

Due to the fact that most of the attributes considered in this study are mostly unobservable, various proxies were used to measure the variables. The dependent variable, market performance, was examined using Tobin's Q (Ankur et al., 2018; Adegboye et al., 2019a). The independent variables adopted in the study were audit committee attributes, including audit committee size, audit committee gender diversity and audit committee expertise (Adeyemo et al., 2016), and board attributes, including board size and board shareholding (Uwuigbe et al., 2018). Control variables were selected based on past research (Ankur et al., 2018; Gehya, 2019). This study included market leverage, return on asset, asset tangibility, firm age and firm size to control for the movement of share prices. All the control variables are expected to either negatively or positively influence market performance.

\subsection{Model specification}

This paper used multiple regression analysis, the static panel regression estimators such as ordinary least square (OLS); fixed effect and random effect were used to explore the subsequent equation. The OLS model disregarded the panel dataset by merging the construct on the variables (Adegboye et al., 
Table 1. Variable definitions

\begin{tabular}{|c|c|c|}
\hline Variables & Acronym & Measurements \\
\hline \multicolumn{3}{|r|}{ Dependent variables } \\
\hline \multirow{2}{*}{ Tobin's Q } & \multirow{2}{*}{ TOBINQ } & Book value of total assets-Book values of equity+Market value of equity \\
\hline & & Book value of total asset \\
\hline \multicolumn{3}{|r|}{ Independent variables } \\
\hline Audit Committee Size & ACSIZE & Overall number of audit committee members \\
\hline $\begin{array}{l}\text { Audit Committee } \\
\text { Gender }\end{array}$ & ACGENDER & Number of females on the board \\
\hline $\begin{array}{l}\text { Audit Committee } \\
\text { Expertise }\end{array}$ & ACEXP & Number of members with financial experience or certification \\
\hline Board Size & BSIZE & Overall number of board members \\
\hline Board Shareholding & BSHARE & Number of shares held by board members to the total number of firm shares. \\
\hline \multicolumn{3}{|r|}{ Control variables } \\
\hline Firm size & SIZE & Natural logarithm of firm's total assets \\
\hline Leverage & LEV & Total liabilities/Total assets \\
\hline Firm asset tangibility & TAN & Ratio of the firm fixed assets to total assets. \\
\hline Return on equity & ROE & Profit after Tax/Total Equity \\
\hline Firm age & AGE & Natural logarithm of year under observation less year of listing on Nigerian stock market. \\
\hline
\end{tabular}

2019b; Detthamrong et al., 2017). The error term of the fixed effect specification assumed a constant variance over time and serially uncorrelated, while the random effect specification controlled for heterogeneity (Boudriga et al., 2010). The study applied the Hausman test to pick the appropriate estimators between random and fixed effects. The regression models are stated as follows:

$$
\begin{aligned}
& \text { Perf }_{i t}=\beta_{0}+\beta_{1} \text { Audit }_{i t}+\beta_{2} \text { Board }_{i t}+ \\
& +\beta_{3} \text { LEV V }_{i t}+\beta_{4} \text { Tan }_{i t}+\beta_{5} \text { Age }_{i t}+ \\
& +\beta_{6} \text { Size }_{i t}+\beta_{7} \text { ROE }_{i t}+\mu_{i t},
\end{aligned}
$$

where $t=$ Annual year for firm $i$; Perf $=$ Market performance; Audit $=$ Audit committee attributes; Board = Board attributes; Lev = Leverage; $R O E=$ Return on equity; Tan = Firm asset tangibility; Age $=$ Firm age; Size $=$ Firm size; and $\mu=$ error term .

\section{RESULTS AND DISCUSSION}

\subsection{Descriptive statistics}

Table 2 summarizes the descriptive statistics of all study variables. It has been observed that market performance (TobinQ) is 0.988 , the observed minimum is 0.834 , while the maximum is 2.604 . Audit committee size has an average of five members approximately, whereas the largest comprised of nine members, and the smallest included three persons only. The average proportion of female membership in the audit committee was approximately 1 , with a maximum of four members, while several businesses had no female members at all. The data revealed that the average number of audit committee members with expertise was 0.842 . Board size arrays from 20 members to seven members with an average of 14 members approximately. The mean of board members ownership was 0.06 , with a maximum of 0.378 and minimum of 0 board ownership. Overall, there is quite no substantial variation in the sample. The dependent

\begin{tabular}{|c|c|c|c|c|}
\hline Variables & Mean & Std. dev. & Min & Max \\
\hline \multicolumn{5}{|c|}{ Market performance } \\
\hline TobinQ & .988 & .228 & .834 & 2.604 \\
\hline \multicolumn{5}{|c|}{ Audit committee attributes } \\
\hline ACSIZE & 5.362 & 1.36 & 3 & 9 \\
\hline ACGENDER & 1.175 & 1.167 & 0 & 4 \\
\hline ACEXP & .842 & .922 & 0 & 3 \\
\hline \multicolumn{5}{|c|}{ Board attributes } \\
\hline BSIZE & 14.233 & 3.191 & 7 & 20 \\
\hline BSHARE & .06 & .093 & 0 & .378 \\
\hline \multicolumn{5}{|c|}{ Control variables } \\
\hline LEV & .365 & .167 & -.498 & .677 \\
\hline Size & 9.157 & .368 & 8.195 & 9.748 \\
\hline ROE & .112 & .141 & -.8 & .275 \\
\hline TAN & .026 & .015 & 0 & .055 \\
\hline Age & 1.052 & .481 & 0 & 1.672 \\
\hline
\end{tabular}
variable shows no wide variation in the sample.

Table 2. Descriptive statistics 
Table 3. Correlation matrix

\begin{tabular}{|c|c|c|c|c|c|c|c|c|c|c|c|}
\hline Variable & TobinQ & ACSIZE & ACGENDER & ACIND & BSIZE & BSHARE & Size & LEV & ROE & TAN & Age \\
\hline TobinQ & 1 & - & - & - & - & - & - & - & - & - & - \\
\hline ACSIZE & -0.0913 & 1 & - & - & - & - & - & - & - & - & - \\
\hline ACGENDER & -0.144 & $0.417^{* *}$ & 1 & - & - & - & - & - & - & - & - \\
\hline ACIND & -0.232 & 0.0678 & $0.302^{*}$ & 1 & - & - & & - & - & - & - \\
\hline BSIZE & $-0.280^{*}$ & 0.0815 & $0.325^{*}$ & 0.241 & 1 & - & - & - & - & - & - \\
\hline BSHARE & -0.101 & 0.0637 & $0.375^{* *}$ & $0.378^{* *}$ & 0.102 & 1 & - & - & - & - & - \\
\hline Size & 0.0265 & $-0.408^{* *}$ & -0.140 & -0.0797 & 0.137 & -0.114 & 1 & - & - & - & - \\
\hline LEV & -0.0341 & -0.0550 & -0.0863 & $0.385^{* *}$ & -0.00920 & -0.00702 & -0.165 & 1 & - & - & - \\
\hline ROE & $0.656^{* * *}$ & $-0.286^{*}$ & -0.185 & $-0.282^{*}$ & 0.00647 & -0.0772 & $0.397^{* *}$ & 0.0406 & 1 & - & - \\
\hline TAN & 0.132 & $0.282^{*}$ & 0.222 & -0.0503 & $0.572^{* * *}$ & -0.184 & -0.272 & 0.0203 & 0.0765 & 1 & - \\
\hline Age & -0.139 & 0.198 & $0.569^{* * *}$ & 0.247 & $0.764^{* * *}$ & $0.276^{*}$ & -0.0106 & 0.0246 & 0.000559 & $0.639^{* * *}$ & 1 \\
\hline
\end{tabular}

Note: $* p<0.05, * * p<0.01$, and $* * * p<0.001$.

\subsection{Correlation matrix}

Table 3 shows the correlation matrix carried out to check for multicollinearity amid the study variables. The table illustrates that the correlation of audit committee and board attributes with firm market characteristics included together in the model specification is minimal. Thus, there is no concern for multicollinearity in the study.

\subsection{Regression analysis}

Table 4 displays the regression results that analyze the modulating influence of audit committee and board attributes on Tobin's Q. However, due to the limitation of OLS regression in financial performance studies, the emphasis was on fixed effect and random effect regression. Moreover, the fixed effect and random effect regressions are presented in Table 4, and the Hausman test suggests that random effect regression is more adequate for inference of the result at a p-value of 0.459 with $R^{2}=0.425$.

The research finds a negative significant relationship between ACSIZE and TobinQ. The negative effect indicates that increased audit size could weaken market performance. This result identifies that committee size should be minimized to effectively function and positively contributes to market performance. The outcomes conform to studies of Al-Matari et al. (2012). However, this disputes the works of Tahir et al. (2014) and Ahmad and Sallau (2018), who instead found a positive association of ACSIZE with performance.

In addition, the results deduce a positively significant influence of ACGENDER on TobinQ. This re- sult promotes the perspective that more diversity in the audit committee is equal to enhanced market performance. Consequently, the amount of female representation in the committee should be increased so as to enhance performance. This follows the studies of Shaba et al. (2016) and RegueraAlvarado et al. (2017), who also revealed a positive association between gender diversity and performance. Though, this disputes the work of Ankur et al. (2018), who found a negative influence on performance. Looking at the ACEXP, increased audit committee expertise positively and significantly influences market performance. This implies that the availability of more members with expertise significantly leads to an increase in market performance. Hence, members of the committee are expected to be proficient financially with the intention of enhancing performance. This imitates the studies of Ojeka et al. (2015) and Osemene and Fakile (2019) with identical positive findings.

Table 4 also inferred that BSIZE negatively and significantly influences market performance at $\mathrm{p}$-value of 0.01 . This specifies that increased board size might not actually translate to better market performance, and large boards are equivalent to more opinions, which might cause conflicts, limit faster decision makings and reduce performance. This replicates the negative results of Maxwell and Kehinde (2012), Shaba et al. (2016) and Adegboye et al. (2019b). However, this disputes the positive verdict of Ahmad and Sallau (2018). Similarly, the study discloses a positive but insignificant influence of BSHARE on market performance. This specifies that a rise in the proportion of shares held by directors might result in greater market performance. So, performance might improve as a conse- 
Table 4. Effects of audit committee and board attributes on market performance

\begin{tabular}{|c|c|c|c|}
\hline Variable & OLS & Fixed effect & Random effect \\
\hline \multirow{2}{*}{ ACSIZE } & $-0.000619 * * *$ & 0.00219 & $-0.000619 * * *$ \\
\hline & $(0.00725)$ & $(0.00826)$ & $(0.00725)$ \\
\hline \multirow{2}{*}{ ACGENDER } & $0.00149 * * *$ & $0.00361 * * *$ & $0.00149 * * *$ \\
\hline & $(0.0100)$ & $(0.0167)$ & $(0.0100)$ \\
\hline \multirow{2}{*}{ ACEXP } & $0.0144 * * *$ & $-0.000511^{* * *}$ & $0.0144 * * *$ \\
\hline & $(0.0110)$ & $(0.0112)$ & $(0.0110)$ \\
\hline \multirow{2}{*}{ BSIZE } & $-0.0127 * * *$ & -0.00706 & $-0.0127^{* * *}$ \\
\hline & $(0.00425)$ & $(0.00559)$ & $(0.00425)$ \\
\hline \multirow{2}{*}{ BSHARE } & 0.00355 & -0.627 & 0.00355 \\
\hline & $(0.117)$ & $(0.472)$ & $(0.117)$ \\
\hline \multirow{2}{*}{ Size } & $-0.0291^{* * *}$ & $-0.280^{*}$ & $-0.0291^{* * *}$ \\
\hline & $(0.0371)$ & $(0.162)$ & $(0.0371)$ \\
\hline \multirow{2}{*}{ LEV } & $-0.118^{* * *}$ & $-0.00318^{* * *}$ & $-0.118 * * *$ \\
\hline & $(0.0863)$ & $(0.101)$ & $(0.0863)$ \\
\hline \multirow{2}{*}{ ROE } & $0.832 * * *$ & 0.217 & $0.832 * * *$ \\
\hline & $(0.136)$ & $(0.252)$ & $(0.136)$ \\
\hline \multirow{2}{*}{ TAN } & $2.217 * *$ & -0.131 & $2.217 * *$ \\
\hline & $(1.073)$ & $(2.465)$ & $(1.073)$ \\
\hline \multirow{2}{*}{ Age } & $-0.00890 * * *$ & $-0.0466 * * *$ & $-0.00890 * * *$ \\
\hline & $(0.0372)$ & $(0.0719)$ & $(0.0372)$ \\
\hline \multirow{2}{*}{ Constant } & $1.286^{* * *}$ & $3.693^{* *}$ & $1.286^{* * *}$ \\
\hline & $(0.348)$ & $(1.536)$ & $(0.348)$ \\
\hline Observations & 52 & 52 & 52 \\
\hline R-squared & 0.633 & 0.384 & 0.425 \\
\hline Rmse & 0.0583 & 0.0493 & 0.0583 \\
\hline F-test & 7.070 & 1.931 & - \\
\hline Prob. $>$ F & 0.0000 & 0.0785 & - \\
\hline Chi-squared & - & - & 70.70 \\
\hline Prob. > chi2 & - & - & 0 \\
\hline Hausman Test & - & - & 38.07 \\
\hline Prob. > chi2 & - & - & 0.459 \\
\hline
\end{tabular}

Note: $* * * p<0.01, * * p<0.05, * p<0.1$.

quence of the directors' will to fulfil their personal interest along with the investors' interests. This mimics the studies of Desoky and Mousa (2012) and Bhagat and Bolton (2013), who also disclosed a positive connection with performance. Meanwhile, this disputes the work of Guo and Kga (2012), who presented a negative link with performance.

Similarly, control variables are significant with the expected signs. It is accordingly expected that in- creased firm size, leverage and firm age will exert a negative and significant influence on market performance, while return on equity and investment in physical assets have a significantly positive association with performance.

Consequently, based on the results of the regression analysis, hypotheses $1,2,3$, and $4\left(H_{1} H_{2} H_{3}\right.$, $\mathrm{H}_{4}$ ) are not supported, but hypothesis $5\left(\mathrm{H}_{5}\right)$ is accepted.

\section{CONCLUSION}

Due to the frequent changes in the corporate environment, corporate governance mechanisms must be extremely up-to-date to provide quality assurance services to various stakeholders. This study explored the degree to which audit committee and board attributes impact market performance of listed deposit money banks in Nigeria. The results concluded that there is a negative and significant link between audit committee size and TobinQ, a positively significant connection between audit committee gender 
diversity, audit committee expertise and TobinQ. The study also revealed that board size has a negative influence on market performance and there is a positive and insignificant influence of board shareholding on market performance. The findings imply that a weak corporate governance structure might lead to lower market performance. Hence, the work recommends that listed deposit money banks should pay more attention to board size by ensuring that the appointment criteria prioritize knowledge and competence. In addition, board composition should be strengthened for efficient supervision and decision making processes. Audit committee size should also be retained to accurately track the financial reporting and auditing operations of a firm. This would increase the market value of banks.

The study was limited by the inability to explore all listed firms in the country and the use of only listed deposit money banks as a sample, which could restrict the general use of the findings. Further research should aim at scrutinizing the association between audit committee attributes, board characteristics and market performance for businesses in other sectors. Further research is needed to introduce new hypotheses and conduct investigations on new variables to represent the impact of the corporate governance mechanisms on bank performance. Additional research can seek to find an association between other governance mechanisms such as the stakeholders' relation committee, risk management committee and the nomination and remuneration committee, and several dividend payout or capital structure decisions. A detailed work that examines qualitative and psychological features of board traits and performance of Nigerian banks could help identify some of the theoretical foundations of corporate governance.

\section{AUTHOR CONTRIBUTIONS}

Conceptualization: Oluwatamilore Omotoye.

Data curation: Tumininu Omotoye, Faith Okeme, Andrew Leigh.

Formal analysis: Faith Okeme.

Funding acquisition: Kingsley Adeyemo.

Investigation: Oluwatamilore Omotoye, Tumininu Omotoye, Faith Okeme, Andrew Leigh.

Methodology: Oluwatamilore Omotoye, Tumininu Omotoye.

Project administration: Oluwatamilore Omotoye, Andrew Leigh.

Resources: Oluwatamilore Omotoye, Tumininu Omotoye.

Software: Tumininu Omotoye, Andrew Leigh.

Supervision: Kingsley Adeyemo.

Validation: Kingsley Adeyemo.

Visualization: Faith Okeme, Andrew Leigh.

Writing - original draft: Oluwatamilore Omotoye.

Writing - reviewing \& editing: Kingsley Adeyemo.

\section{ACKNOWLEDGMENT}

The authors would like to acknowledge Covenant University for its financial support during the course of this research paper.

\section{REFERENCES}

1. Abad, D., Lucas-Perez, M., Minguez-Vera, A., \& Yague, J. (2017). Does gender diversity on corporate boards reduce information asymmetry in equity markets? Business Research Quarterly, 20(3), 192-205. https:// doi.org/10.1016/j.brq.2017.04.001

2. Acharya, B. (2017). The unfinished agenda: Restoring public sector bank health in India. Retrieved from https://rbidocs.rbi.org. in/rdocs/Speeches/PDFs/ IIBFVA09072017437215F-
BE69A442CB8E227778F5A2B23. PDF

3. Adegboye, A., Ojeka, S., Adegboye, K., Alabi, O., Afolabi, M., \& Iyoha, F. (2019a). Data on chief financial officer attributes and risk management strategies 
for Nigerian listed financial institutions. Data in brief, 27, 104609. https://doi.org/10.1016/j. dib.2019.104609

4. Adegboye, A., Ojeka, S., Adegboye, K., Ebuzor, E., \& Samson, D. (2019b). Firm performance and condensed corporate governance mechanism: Evidence of Nigerian financial institutions. Business: Theory and Practice, 20, 403 416. https://doi.org/10.3846/ btp. 2019.38

5. Adeyemo, K.A. (2012). Frauds in Nigerian banks: Nature, deepseated causes, aftermaths and probable remedies. Mediterranean Journal of Social Sciences, 3(2), 279-289. Retrieved from http:// www.richtmann.org/journal/index.php/mjss/article/view/11022

6. Adeyemo, K.A., Eriabe, O., Adetiloye, K., \& Egbide, B. (2016). Audit committee attributes and financial reporting quality in Nigerian quoted companies. International Business Management, 10(22), 5326-5335. http://dx.doi.org/10.36478/ ibm.2016.5326.5335

7. Adeyemo, K.A., Isiavwe, D., Adetula, D., Olamide, O., \& Owolabi, F. (2020). Mandatory adoption of Central Bank of Nigeria's cashless and e-payment policy: Implication for banks' customers. Banks and Bank Systems, 15(2), 243253. https://doi.org/10.21511/ bbs.15(2).2020.21

8. Afza, T., \& Nazir, M. (2014). Audit quality and firm value: A case of Pakistan. Research Journal of Applied Science, Engineering and Technology, 7(9), 1803-1810. http://dx.doi.org/10.19026/rjaset.7.465

9. Aguilera, R., \& Jackson, G. (2010). Comparative and international corporate governance. The Academy of Management Annals, 4(1), 485-556. https://doi.org/10.5 465/19416520.2010.495525

10. Ahmad, H., \& Sallau, M. M. (2018). Corporate governance and market value of listed deposit money banks in Nigeria. Accounting \& Taxation Review, 2(2), 28-42. Retrieved from http://atreview.org/ad$\min / 12389900798187 /$ atr\%20 2\%20(2)\%20Jun\%202018\%20 pp\%2028-42_\%20Ahmad\%20 $\& \% 20$ Sallau(1).pdf

11. Aldamen, H., Hollindale, J., \& Ziegelmayer, J. (2018). Female audit committee members and their influence on audit fees. Accounting \& Finance, 58(1), 57-89. https://doi.org/10.1111/ acfi. 12248

12. Allegrini, M., \& Greco, G. (2011). Corporate boards, audit committees and voluntary disclosure: evidence from Italian Listed Companies. Journal of Management and Governance, 17(1), 187-216. https://doi. org/10.1007/s10997-011-9168-3

13. Al-Matari, Y., Al-Swidi, A., Fadzil, F., \& Al-Matari, E. (2012). Board of directors, audit committee characteristics and the performance of Saudi Arabia listed companies. International Review of Management and Marketing, 2(4), 241-251. Retrieved from http://www.econjournals.com/index.php/irmm/ article/view/303

14. Al-Saidi, M., \& Al-Shammari, B. (2013). Board composition and bank performance in Kuwait: An empirical study. Managerial Auditing Journal, 28(6), 472-494. https://doi. org/10.1108/02686901311329883

15. Andreou, P., Antoniou, C., Horton, J., \& Louca, C. (2016). Corporate governance and firm-specific stock price crashes. European Financial Management, 22(5), 916-956. https://doi.org/10.1111/ eufm.12084

16. Ankur, S., Sivasankaran, N., \& Shilpee, A. (2018). Do board characteristics impact the market performance of Indian banks? Asian Economic and Financial Review, Asian Economic and Social Society, 8(11), 13651383. Retrieved from https:// doi.org/10.18488/journal. aefr.2018.811.1365.1383

17. Asiriuwa, O., Aronmwan, E., Uwuigbe, U., \& Uwuigbe, O. (2018). Audit committee attributes and audit quality: A benchmark analysis. Business: Theory and Practice, 19, 37-48. https://doi. org/10.3846/btp.2018.05

18. Awinbugri, A., \& Prince, G. (2019). The impact of audit committees' meetings and audit fees on the financial performance of listed banks in Ghana. International Journal of Research and Innovation in Social Science, 3(5), 341-346. Retrieved from https://www. rsisinternational.org/journals/ ijriss/Digital-Library/volume3-issue-5/341-346.pdf

19. Bebeji, A., Mohammed, A., \& Tanko, M. (2015). The effect of board size and composition on the financial performance of banks in Nigeria. African Journal of Business Management, 9(16), 590-598. https://doi.org/10.5897/ AJBM2015.7797

20. Berger, A., \& Patti, E. (2002). Capital structure and firm performance: A new approach to testing agency theory and an application to the banking industry. Journal of Social and Economic Research, 4(4), 1220. Retrieved from https:// www.federalreserve.gov/pubs/ feds/2002/200254/200254pap.pdf

21. Bhagat, S., \& Bolton, B. (2013). Director ownership, governance, and performance. Journal of Financial \& Quantitative Analysis, 48(1), 105-135. https://doi. org/10.1017/S0022109013000045

22. Bhasin, M. (2013). Corporate accounting scandal at Satyam: A case study of India's Enron. European Journal of Business and Social Sciences, 1(12), 25-47. Retrieved from https:// www.researchgate.net/publication/271133751_CORPORATE_ ACCOUNTING_SCANDAL_AT_ SATYAM_A_CASE_STUDY_OF_ INDIA'S_ENRON

23. Bilal, Z. O., Twafik, O. I., \& Bakhit, A. K. (2018). The influence of internal auditing on effective corporate governance in the banking sector in Oman. European Scientific Journal, 14(7). https://doi.org/10.19044/esj.2018. v14n7p257

24. Blose, L., \& Shieh, J. (1997). Tobin's Q-Ratio and market 
reaction to capital investment announcements. Financial Review, 32(3), 449-476. https:// doi.org/10.1111/j.1540-6288.1997. tb00434.x

25. Boudriga, A., Taktak, N., \& Jellouli, S. (2010). Bank specific, business and institutional environment determinants of banks non-performing loans: Evidence from MENA countries. In Economic Research Forum, 547, 1-28. Retrieved from https://www.researchgate.net/ publication/254411009_Bank_ Specific_Business_and_Institutional_Environment_Determinants_of_Banks_Nonperforming_Loans_Evidence_from_ MENA_Countries

26. Claessens, S., \& Yurtoglu, B. (2013). Corporate governance in emerging markets: A survey. Emerging Markets Review, 15, 1-33. https://doi.org/10.1016/j.ememar.2012.03.002

27. Desoky, A., \& Mousa, G. (2012). Do board ownership and characteristics affect firm performance? Evidence from Egypt. Global Advanced Research Journal of Economics, Accounting and Finance, 1(2), 15-32.

Retrieved from http://garj.org/ garjeaf/12/2012/1/2/do-boardownership-and-characteristicsaffect-on-firm-performance-evidence-from-egypt

28. Detthamrong, U., Chancharat, N., \& Vithessonthi, C. (2017). Corporate governance, capital structure and firm performance: Evidence from Thailand. Research in International Business and Finance, 42, 689-709. https://doi. org/10.1016/j.ribaf.2017.07.011

29. Elmagrhi, M., Ntim, C., Crossley, R., Malagila, J., Fosu, S., \& Vu, T. (2017). Corporate governance and dividend pay-out policy in UK listed SMEs: The effects of corporate board characteristics. International Journal of Accounting \& Information Management, 25(4), 459-483. https://doi.org/10.1108/ IJAIM-02-2017-0020

30. Eluyela, D., Akintimehin, O., Okere, W., Ozordi, E., Osuma, G., Ilogho, S., \& Oladipo, O. (2018). Board meeting frequency and firm performance: Examining the nexus in Nigerian deposit money banks. Heliyon, 4(10). https://doi. org/10.1016/j.heliyon.2018.e00850

31. Gehya, E. (2019). Impact of audit committee attributes on financial reporting quality of deposit money banks in Nigeria. Research Journal of Finance and Accounting, 10(4), 22-34. https:// doi.org/10.7176/RJFA/10-4-04

32. Guo, Z., \& Kga, U. (2012). Corporate governance and firm performance of listed firms in Sri Lanka. Procedia-Social and Behavioral Sciences, 40, 664-667. https://doi.org/10.1016/j.sbspro.2012.03.246

33. Hassan, Y. (2010). Corporate governance mechanisms and performance of deposit money banks in Nigeria (MSc Thesis). Ahmadu Bello University, Zaria, Kaduna State-Nigeria.

34. Hay, D., Stewart, J., \& Botica, N. (2017). The role of auditing in corporate governance in Australia and New Zealand. Australian Accounting Review, 27(4), 457-479. https://doi.org/10.1111/auar.12190

35. Hussainey, K., \& Wang, M. (2010). The impact of corporate governance on future-oriented disclosures: $a$ large-scale UK study (Working Paper). Stirling University.

36. Ibrahim, E., \& Al harasees, M. (2019). Gender attributes of audit committee members and the quality of financial reports. International Journal of Academic Research in Accounting, Finance and Management Sciences, 9(3), 24-37. http://dx.doi.org/10.6007/ IJARAFMS/v9-i3/6323

37. Isik, O., \& Ince, A. (2016). Board size, board composition and performance: An investigation on Turkish banks. International Business Research, 9(2), 7484. https://doi.org/10.5539/ibr. v9n2p74

38. Istance, D., \& Kools, M. (2013). OECD work on technology and education: Innovative learning environments as an integrating framework. European Journal of Education, 48(1), 43-57. https:// doi.org/10.1111/ejed.12017
39. Jadah, H., \& Adzis, A. (2016). The effect of board characteristics on Iraqi banks performance. International Journal of Academic Research in Accounting, Finance and Management Sciences, 6(4), 205-214. Retrieved from https:// ideas.repec.org/a/hur/ijaraf/ v6y2016i4p205-214.html

40. Jensen, M., \& Meckling, W. (1976). Theory of the firm: Managerial behavior, agency costs and ownership structure. Journal of Financial Economics, 3(4), 305360. https://doi.org/10.1016/0304405X(76)90026-X

41. Juhmani, O. (2017). The impact of audit committee characteristics on earnings management in the pre and post Bahraini corporate governance code 2011. Asian Journal of Economics, Business and Accounting, 4(3), 1-12. https://doi. org/10.9734/AJEBA/2017/36234

42. Kakanda, M., Bello, A., \& Abba, M. (2016a). Effect of capital structure on the performance of listed consumer goods companies in Nigeria. Research Journal of Finance and Accounting, 7(8), 211-219. Retrieved from https:// www.academia.edu/24920369/ Effect_of_Capital_Structure_on_ Performance_of_Listed_Consumer_Goods_Companies_in_Nigeria

43. Kakanda, M., Salim, B., \& Chandren, S. (2016b). Review of the relationship between board attributes and firm performance. Asian Journal of Finance and Accounting, 8(1), 168-218. https:// doi.org/10.5296/ajfa.v8i1.9319

44. Kibiya, M., Ahmad, A., \& Amran, N. (2016). Audit committee characteristics and financial reporting quality: Nigerian non-financial listed firms. The European Proceeding of Social \& Behavioral Sciences (pp. 753-760). Retrieved from https://www.europeanproceedings.com/files/data/ article/44/1138/article_44_1138_ pdf_100.pdf

45. Li, J., Mangena, M., \& Pike, R. (2012). The effect of audit committee characteristics on intellectual capital disclosure. The British Accounting Review, 44(2), 98-110. https://doi.org/10.1016/j. bar.2012.03.003 
46. Lustgarten, S., \& Thomadakis, S. (1987). Mobility barriers and Tobin's Q. The Journal of Business, 60(4), 519-537. http://dx.doi. org/10.1086/296411

47. Marn, J., \& Romuald, D. (2012). The impact of corporate governance mechanism and corporate performance: A study of listed companies in Malaysia. Journal of Advanced Science and Arts, 3(1), 31-45. Retrieved from https://www.researchgate.net/ publication/331327355_The_Impact_of_Corporate_Governance_ Mechanism_and_Corporate performance_A_study_of_Listed_ Companies_in_Malaysia

48. Maxwell, O., \& Kehinde, E. (2012). Corporate governance and bank performance in Nigeria: A correlation analysis. Economics and Finance Review, 2(4), 14-23.

49. Mohiuddin, M., \& Karbhari, Y. (2010). Audit committee effectiveness: A critical literature review. AIUB Journal of Business and Economics, 9(1), 97-125. Retrieved from https://www. researchgate.net/publication/281224861_Audit_Committee_Effectiveness_A_Critical_Literature_Review

50. Mwangi, A., Oluoch, J., Muturi, W., \& Florence, M. (2017). Effect of audit committee diversity on quality of financial reporting in non-commercial state corporations in Kenya. International Journal of Academic Research in Business and Social Sciences, 7(6), 288-302. Retrieved from https://ideas.repec.org/a/ hur/ijarbs/v7y2017i6p288-302. html

51. Ntim, C., \& Osei, K. (2011). The impact of corporate board meetings on corporate performance in South Africa. African Review of Economics and Finance, 2(2), 83-103. Retrieved from https://eprints.soton. ac.uk/343111/

52. Ntim, C., \& Soobaroyen, T. (2013). Corporate governance and performance in socially responsible corporations: New empirical insights from a Neo-Institutional framework.
Corporate Governance: An International Review, 21(5), 468494. https://doi.org/10.1111/ corg.12026

53. Nwokah, N., \& Ahiauzu, A. (2010). Marketing in governance: emotional intelligence leadership for effective corporate governance. Corporate Governance, 10(2), 150-162. https://doi. org/10.1108/14720701011035675

54. Ogura, Y. (2018). The objective function of governmentcontrolled banks in a financial crisis. Journal of Banking \& Finance, 89, 78-93. https:// doi.org/10.1016/j.jbankfin.2018.01.015

55. Ojeka, S., Adegboye, A., Adegboye, K., Alabi, O., Afolabi, M., \& Iyoha, F. (2019a). Chief financial officer roles and enterprise risk management: An empirical based study. Heliyon, 5(6), e01934. https://doi.org/10.1016/j.heliyon.2019.e01934

56. Ojeka, S., Adegboye, A., Adegboye, K., Umukoro, O., Dahunsi, O., Ozordi, E. (2019b). Corruption perception, institutional quality and performance of listed companies in Nigeria. Heliyon, 5(10). https://doi.org/10.1016/j. heliyon.2019.e02569

57. Ojeka, S., Iyoha, F., \& Asaolu, T. (2015). Audit committee financial expertise: Antidote for financial reporting quality in Nigeria. Mediterranean Journal of Social Sciences, 6(1), 136-146. http:// dx.doi.org/10.5901/mjss.2015. v6n 1 p 136

58. Ojeka, S., Iyoha, F., \& Obigbemi, I. (2014). Effectiveness of audit committee and firms' financial performance in Nigeria: An empirical analysis. Journal of Accounting and Auditing: Research \& Practice. https://doi. org/10.5171/2014.301176

59. Oliver, O., \& Grace, N. (2017). Effect of audit committee qualities on financial reporting of listed companies in Nigeria: A perspective study. International Journal of Scientific and Research Publications, 7(10). Retrieved from https://www.researchgate. net/publication/320577331_Ef-
fect_of_Audit_Committee_Quality_on_Financial_Reporting_of_ Listed_Companies_in_Nigeria_A_ Perspective_Study

60. Osemene, O., \& Fakile, O. (2019). Effectiveness of audit committee and financial performance of deposit money banks in Nigeria. Fountain University Oshogbo Journal of Management, 3(3). Retrieved from https://osogbojournalofmanagement.com/index. $\mathrm{php/ojm/article/view/76}$

61. Osundina, J., Olayinka, I., \& Chukwuma, J. (2016). Corporate governance and financial performance of selected manufacturing companies in Nigeria. International Journal of Advanced Academic Research, 2(1), 29-43. Retrieved from https:// www.ijaar.org/articles/Volume2 Number10/Social-ManagementSciences/ijaar-sms-v2n9-sep16-p9. pdf

62. Pathan, S., \& Faff, R. (2013). Does board structure in banks really affect their performance? Journal of Banking \& Finance, 37(5), 15731589. https://doi.org/10.1016/j. jbankfin.2012.12.016

63. Pillai, R., \& Al-Malkawi, H. (2018). On the relationship between corporate governance and firm performance: Evidence from GCC countries. Research in International Business and Finance, 44, 394-410. https://doi. org/10.1016/j.ribaf.2017.07.110

64. Reguera-Alvarado, N., De Fuentes, P., \& Laffarga, J. (2017). Does board gender diversity influence financial performance? Evidence from Spain. Journal of Business Ethics, 141(2), 337-350. https://doi. org/10.1007/s10551-015-2735-9

65. Scholtz, H., \& Engelbrecht, W. (2015). The effect of remuneration committees, directors' shareholding and institutional ownership on the remuneration of directors in the top 100 companies in South Africa. Southern African Business Review, 19(2), 22-51. Retrieved from https://www. ajol.info/index.php/sabr/article/ view/124746

66. Shaba, Y., Abubakar, I., \& Yaaba, B. (2016). Corporate governance and 
market performance: Empirical evidence from Nigerian banks. International Journal of research in management, economics and commerce, 6(12), 9-20. Retrieved from https://www.academia. edu/30855698/Corporate_Governance_and_Market_Performance_ Empirical_Evidence_from_Nigerian_Banks

67. Shan, Y., \& Mclver, R. (2011). Corporate governance mechanisms and financial performance in China: Panel data evidence on listed non-financial companies. Asia Pacific Business Review, 17(3), 301-324. https://doi. org/10.1080/13602380903522325

68. Sharma, D. (2018). Stock Market Performance and Efficiency of Banks in a Developing Economy: Evidence from the Indian Banking Sector. IIM Kozhikode Society \& Management Review, 7(2), 178-193. https://doi. org/10.1177/2277975218770502

69. Shukla, A., Sivasankaran, N., \& Dasgupta, S. (2018). Do board characteristics impact the market performance of Indian banks?
Asian Economic and Financial Review, 8(11), 1365-1383.

Retrieved from https://ideas.repec. org/a/asi/aeafrj/2018p1365-1383. html

70. Tahir, S., Rehman, R., \& Rehman, N. (2014). Corporate governance and financial leverage impact on the value of firms. Research Journal of Economics and Business Studies, 3(6), 251-265. Retrieved from https://www.theinternationaljournal.org/ojs/index.php?journ al=rjebs\&page $=$ article $\& o p=$ view \&path\%5B\%5D=2773\&path\%5B $\% 5 \mathrm{D}=\mathrm{pdf}$

71. Uwuigbe, O. (2013). Corporate governance and share price: Evidence from listed firms in Nigeria. African Research Review, 7(2), 129-143. Retrieved from https://www.academia. edu/15087672/Corporate_Governance_and_Share_Price_Evidence_from_listed_Firms_in_Nigeria

72. Uwuigbe, U., Eluyela, D., Uwuigbe, O., Obarakpo, T., \& Falola, I.

(2018). Corporate governance and quality of financial statements: A study of listed Nigerian banks.

73. World Bank. (2011). Improving Corporate Governance in Emerging Markets.

74. Zabri, S. M., Ahmad, K., \& Wah, K. K. (2016). Corporate governance practices and firm performance: Evidence from top 100 public listed companies in Malaysia. Procedia Economics and Finance, 35, 287-296. https://doi.org/10.1016/S22125671(16)00036-8

75. Zraiq, M., \& Fadzil, F. (2018a). The impact of audit committee characteristics on firm performance: Evidence from Jordan. Scholar Journal of Applied Science and Research, 1, 39-42. https://innovationinfo.org/articles/ SJASR-5-154.pdf

76. Zraiq, M., \& Fadzil, F. (2018b). The impact of ownership structure on firm performance: Evidence from Jordan. International Journal of Accounting, Finance and Risk Management, 3(1), 1-4. https://doi. org/10.11648/j.ijafrm.20180301.12 